\title{
Amelia Creek: a Proterozoic impact structure in the Davenport Ranges, Northern Territory
}

\author{
F. A. MACDONALD, ${ }^{1 *}$ K. MITCHELL ${ }^{2}$ AND A. J. STEWART ${ }^{3}$
}

'Department of Earth and Planetary Sciences, Harvard University, 20 Oxford Street, Cambridge, MA 02138, USA.

281 Fern Street, Gerringong, NSW 2534, Australia.

${ }^{3} 23$ Vasey Crescent, Campbell, ACT 2612, Australia.

\begin{abstract}
The Amelia Creek impact structure is located in Australia's Northern Territory in folded PalaeoproterOzoic strata of the Davenport Ranges ( $20^{\circ} 51^{\prime} \mathrm{S}, 134^{\circ} 53^{\prime} \mathrm{E}$ ). An impact origin is confirmed by presence of unequivocal shatter cones with apices that point upwards, and by planar microstructures in quartz grains from target sandstones of the Hatches Creek Group. Aeromagnetic, advanced spaceborne thermal emission and reflection radiometer (ASTER), and X-band synthetic aperture radar (X-SAR) images show an area of anomalous deformation in which smooth regional trends are disrupted by arcuate features at a $10 \mathrm{~km}$ radius to the north and south of the shock-metamorphosed rocks. However, no arcuate forms are apparent to the east and west of these shocked rocks, and instead, large south-southwest-trending faults are present about $6 \mathrm{~km}$ away on both sides. Despite pervasive shatter coning, typical of the central region of complex impact structures, no structural uplift is apparent, but instead the shocked rocks lie at the southern toe of a north-northeast-trending syncline. These shatter cones overprint and post-date the Palaeoproterozoic regional deformation, and thus, the impact structure has not been refolded and its abnormal form is likely due to pre-existing structure in the target rocks and/or an oblique impact. Small pockets of undeformed Late Neoproterozoic and Middle Cambrian strata are exposed in palaeovalleys in the central region of the structure, constraining the time of the impact to the Proterozoic.
\end{abstract}

KEY WORDS: aeromagnetic images, Amelia Creek, Davenport Ranges, Hatches Creek Group, impact structures, oblique impact, shatter cones.

\section{INTRODUCTION}

The identification of shatter cones as a shock-metamorphic feature diagnostic of hypervelocity impact (Dietz 1959; Roddy \& Davis 1977; French 1998) has permitted the discovery of ancient terrestrial impact structures in complex terrains where little or no circular morphological or geophysical signatures exist (Hargraves et al. 1990; Macdonald et al. 2003). However, in a geologically complex region, even after determining that an area has been shock metamorphosed, sorting out the relationship between impact-generated deformation and tectonism can be difficult. In this contribution, we present a newly discovered impact structure that is situated within a Proterozoic fold belt, but lacks a central uplift and a circular form.

The Amelia Creek impact structure is situated in the Davenport Ranges of the Northern Territory (20 51'S, $134^{\circ} 53^{\prime} \mathrm{E}$ : Figure 1). It is named after Amelia Creek, whose headwaters, typically dry creek beds, bifurcate around the centre of the structure. Conical jointing was first observed at Amelia Creek by Alastair Stewart and Ken Mitchell in 1981 during regional geological mapping of the Bonney Well 1:250 000 map sheet area. Macdonald and Mitchell visited the area in 2002 and again in 2003, and reinterpreted this jointing as shock-induced shatter coning.

\section{GEOLOGICAL SETTING}

The Amelia Creek impact structure is formed in sedimentary and volcanic rocks of the Palaeoproterozoic Hatches Creek Group, which are exposed in the Tennant Creek Inlier (Figure 1). The Hatches Creek Group was deposited before $1700 \mathrm{Ma}$ and was metamorphosed to greenschist facies and deformed by northwest-trending folds, and subsequent north-northeast-trending folds, before the emplacement of granites at $c a 1660 \mathrm{Ma}$ (Blake et al. 1987). Locally, the Hatches Creek Group is unconformably overlain by thin sequences of Late Neoproterozoic, Cambrian, and Cenozoic sedimentary rocks. The Tennant Creek Inlier contains at least one other large impact structure referred to as Kelly West $\left(19^{\circ} 56^{\prime} \mathrm{S}, 133^{\circ} 57^{\prime} \mathrm{E}\right.$ : Shoemaker \& Shoemaker 1996). The Wessel structure, a $\sim 1.6 \mathrm{~km}$ diameter circular geophysical anomaly located $\sim 30 \mathrm{~km}$ to the northeast of the Amelia Creek structure, may also be of impact origin (Figure 1) (Macdonald \& Mitchell 2004).

*Corresponding author: fmacdon@fas.harvard.edu 


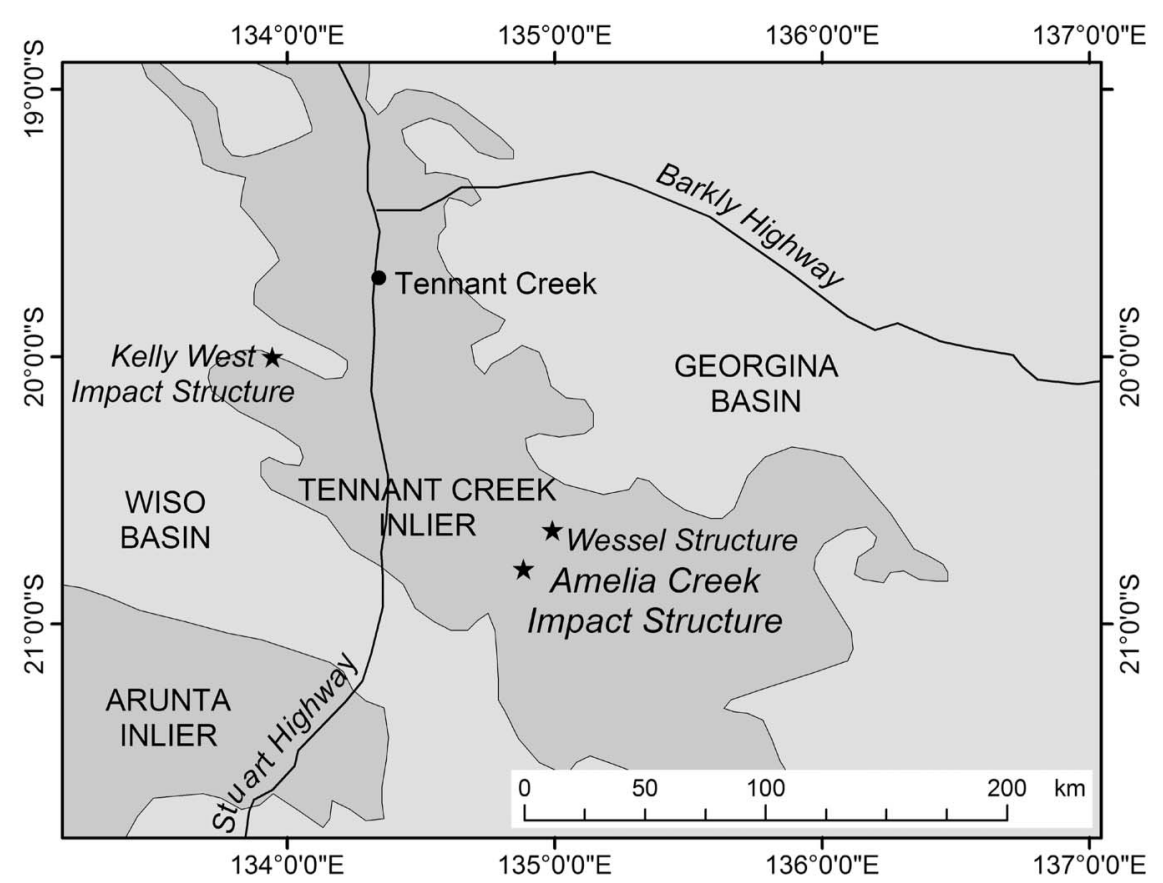

Figure 1 Location map with major geological provinces. The dark areas are Proterozoic composite terrains and lighter regions represent Palaeozoic basins.

\section{STRATIGRAPHY}

The Palaeoproterozoic Hatches Creek Group is divided into Ooradidgee, Wauchope and Hanlon Subgroups, in ascending order (Blake et al. 1987), all of which are represented at the Amelia Creek structure (Table 1; Figure 2). The Hatches Creek Group is composed primarily of well-bedded sandstones in transgressiveregressive cycles, and felsic and mafic volcanic rocks. Cross-beds and ripple marks are ubiquitous in aeolian and beach sandstones.

Only the uppermost formations of the Ooradidgee Subgroup are exposed in the Amelia Creek structure. The oldest formation is the Edmirringee Basalt, which outcrops poorly in anticlines south and west of the structure. These rocks are overlain by the Kurinelli Sandstone, which is composed primarily of mediumbedded, recessive, friable, feldspathic arenite and siltstone. The Kurinelli Sandstone also contains felsic and mafic volcanics, which may have erupted during the same magmatic episode that produced the Edmirringee Basalt (Blake et al. 1987). The Kurinelli Sandstone rests below the white ridge-forming Taragan Sandstone. At Amelia Creek, faults have typically formed along the contact between these two formations.

The Ooradidgee Subgroup is overlain by the Unimbra Sandstone, which is the basal unit of the Wauchope Subgroup. The Unimbra Sandstone is a white, ridgeforming quartzo-feldspathic to lithic arenite, commonly with large cross-beds. It is about $400 \mathrm{~m}$ thick and contains minor pebble conglomerate beds and rare ripple marks. Most of the shatter cones at Amelia Creek are found in the Unimbra Sandstone. These beds lie below the recessive, valley-forming Yeeradgi Sandstone, which near Amelia Creek is composed primarily of feldspathic volcanics, volcaniclastics, brown siltstone and shale. The Yeeradgi Sandstone is typically around
$400 \mathrm{~m}$ thick and is strongly foliated. The Coulters Sandstone was deposited above the Yeeradgi Sandstone and is lithologically very similar to the Unimbra Sandstone. The Wauchope Subgroup terminates with the Kudinga Basalt, which is around $300 \mathrm{~m}$ thick and is composed of deeply weathered, recessive, mediumgrained basalt, and quartz or lithic arenite.

The Hanlon Subgroup forms the upper part of the Hatches Creek Group and crops out in the central syncline at the Amelia Creek structure (Figure 3a). Near Amelia Creek, this subgroup is $\sim 900 \mathrm{~m}$ thick and is composed of three, buff-coloured sandstone units (Errolola Sandstone, Alinjabon Sandstone and Lennee Creek Formation) which are separated by recessive siltstones and felsic volcaniclastics. The Lennee Creek Formation also contains some red shale in its upper part.

Within the central region of the Amelia Creek structure, palaeovalleys carved into the recessive Yeeradgi Sandstone are filled with sedimentary rocks (Figure $3 \mathrm{~b}$ ) of the Neoproterozoic Andagera Formation and Cambrian Gum Ridge Formation. The palaeovalley fill constitutes ancient river terraces (Stewart et al. 1986a) that are relatively undeformed and post-date the impact event. Subhorizontal dips in these units probably represent compaction and slumping. Haines et al. (1991) demonstrated that the Andagera Formation's fluvial conglomerates can be traced laterally southeast into the thicker deltaic and shallow-marine sandstonedominated succession of the Georgina Basin. The type section of the Andagera Formation appears to be nearly identical to the Central Mt Stuart Formation farther west and south (P. Haines pers. comm. 2004). The Central Mt Stuart Formation contains Late Neoproterozoic body and trace fossils (Mt Skinner fauna) and is separated by a disconformity from Lower Cambrian trace-fossil-rich marine clastics and carbonates. Like the Andagera Formation, the Central Mt Stuart Formation also locally fills erosional incisions in Hatches 
Table 1 Stratigraphy of the Amelia Creek Structure (after Blake et al. 1987 and Haines et al. 1991).

\begin{tabular}{|c|c|c|c|c|}
\hline Map symbol & Approximate age (Ma) & Lithological unit & Maximum thickness (m) & Description \\
\hline Qal & Quaternary & Cover & 20 & Mixed colluvial and alluvial sand, silt \\
\hline \multicolumn{5}{|c|}{$\sim \sim \sim \sim \sim \sim \sim \sim \sim \sim \sim \sim \sim \sim \sim \sim \sim \sim \sim \sim \sim \sim \sim \sim \sim \sim \sim \sim$ uncohformity $\sim \sim \sim \sim \sim \sim \sim \sim \sim \sim \sim \sim \sim \sim \sim \sim \sim \sim \sim \sim \sim \sim \sim \sim \sim \sim \sim \sim$} \\
\hline $\mathrm{Cg}$ & Cenozoic & Laterite & 50 & Silcrete and ferricrete \\
\hline Czc & Cenozoic & Conglomerate & 50 & Silicified pebble conglomerate \\
\hline \multicolumn{5}{|c|}{$\sim \sim \sim \sim \sim \sim \sim \sim \sim \sim \sim \sim \sim \sim \sim \sim \sim \sim \sim \sim \sim \sim \sim \sim \sim \sim \sim \sim$ uncohformity $\sim \sim \sim \sim \sim \sim \sim \sim \sim \sim \sim \sim \sim \sim \sim \sim \sim \sim \sim \sim \sim \sim \sim \sim \sim \sim \sim \sim$} \\
\hline $\mathrm{Cb}$ & Cambrian & Gum Ridge Fm & 10 & \multirow{3}{*}{$\begin{array}{l}\text { Chert and cherty breccia } \\
\text { Poorly sorted fluvial sandstone and } \\
\text { conglomerate with pitted weathering } \\
\text { surfaces } \\
\sim \sim \sim \sim \sim \sim \sim \sim \sim \sim \sim \sim \sim \sim \sim \sim \sim \sim \sim\end{array}$} \\
\hline $\mathrm{Pa}$ & Neoproterozoic ca 600 & Andagera Fm & 30 & \\
\hline$\sim \sim \sim \sim \sim \sim$ & $\sim \sim \sim \sim \sim \sim \sim \sim \sim \sim \sim$ & $\sim \sim \sim \sim$ unconformity & minimum age of impact & \\
\hline \multicolumn{5}{|c|}{ NW- and subsequent NNE-trending folding followed by granite emplacement at ca $1640 M a^{\mathrm{a}}$} \\
\hline $\mathrm{Ph}$ & Palaeoproterozoic & Hatches Creek Group & & \multirow{5}{*}{$\begin{array}{c}\text { Three }>100 \text { m-thick massive cross- } \\
\text { bedded arenites separated by recessive } \\
\text { siltstones and volcanics }\end{array}$} \\
\hline \multirow[t]{4}{*}{ Phh } & $>1660^{\mathrm{a}}$ & Hanlon Subgroup & & \\
\hline & & Lennee Creek Fm & 300 & \\
\hline & & Alinjabon Ss & 300 & \\
\hline & & Errolola Ss & 300 & \\
\hline \multirow[t]{5}{*}{ Phw } & $>1660^{\mathrm{a}}$ & Wauchope Subgroup & & \multirow{5}{*}{$\begin{array}{l}\text { Massive white cross-bedded aeolian } \\
\text { and shallow-marine arenites with } \\
\text { minor recessive foliated basalts, felsic } \\
\text { volcanics and volcaniclastics }\end{array}$} \\
\hline & & Kudinga Basalt & 300 & \\
\hline & & Coulters Ss & 500 & \\
\hline & & Yeeradji Ss & 400 & \\
\hline & & Unimbra Ss & 400 & \\
\hline \multirow[t]{4}{*}{ Pho } & ca $1815^{\mathrm{a}}$ & Ooradigee Subgroup & & \multirow{4}{*}{$\begin{array}{c}\text { Recessive red siltstones and } \\
\text { volcaniclastics with interbedded } \\
\text { sandstone capped by }<100 \mathrm{~m} \text { of white } \\
\text { arenite }\end{array}$} \\
\hline & & Taragan Ss & 100 & \\
\hline & & Kurinelli Ss & 400 & \\
\hline & & Edmirringee Basalt & $?$ & \\
\hline
\end{tabular}

${ }^{\mathrm{a}}$ Whole-rock $\mathrm{Rb} / \mathrm{Sr}$ dates from Blake et al. (1987).

Creek Group arenites. In the Amelia Creek structure, the Gum Ridge Formation is up to $10 \mathrm{~m}$ thick and composed of chert and cherty breccias. Using apatite fission track thermochronometry and cosmogenic isotope analyses, Belton et al. (2004) concluded that the Davenport Ranges were buried by $\sim 1 \mathrm{~km}$ of sediment in the Mesozoic. It appears that the Davenport Ranges were covered for much of the Phanerozoic and were only recently exhumed to expose these palaeovalleys.

Many mesas, knobs and local highs within valleys are lateritised and silicified, including one particularly highly folded and brecciated region within the central syncline. Silicified Cenozoic conglomerates also crop out in the broad valleys. Much of the recessive, valleyforming Proterozoic units are covered by Quaternary colluvium.

\section{AMELIA CREEK STRUCTURE}

The Amelia Creek structure lies in an area of multiple fold interference. Broadly, the structure is situated on the north limb of a northwest-trending anticline with a wavelength of $\sim 20 \mathrm{~km}$; however, the pervasively shatter-coned strata are primarily restricted to two kilometresized fault blocks at the toe of a shorter, superimposed north-northeast-trending syncline (Figure 2) (see Stewart et al. 1986b for a regional view). This central syncline (Figure 3a) is one of four north-plunging folds near the margin of the buttress-like Taragan Block, suggesting that these secondary folds resulted from compression against this structural boundary (Stewart 1987). Although the western margin of the western shocked block is flanked by a large fault with $\sim 0.5 \mathrm{~km}$ of displacement, the stratigraphic sequence within the blocks appears identical to that on the limbs of the central syncline, that is, the shatter cones are autochthonous. Moreover, rare shatter cones are found to the west of this large fault. Whether or not the displacement on these blocks was impact generated is unclear. Nonetheless, there appears to be no structural uplift associated with the central shocked rocks, but rather, a southward movement of these blocks that is difficult to differentiate from displacement associated with the north-trending folding and east-west shortening. Around the central syncline, several smaller divergently plunging folds occur near the base of the Unimbra Sandstone (Figure 2). The chaotic orientations of these folds indicate that they may have been impact generated.

To the north-northeast and south-southwest, the surrounding strata form an arcuate array around the central shocked rocks to about a $20 \mathrm{~km}$ diameter (Figures 2, 4, 5). These trends correspond with a series of folds with arcuate north-inclined axial surfaces that occur in the Hanlon Subgroup $\sim 6 \mathrm{~km}$ south of the central syncline (Figure 2). This folding is concentric around the shocked rocks, and appears to be unrelated to the north-northeast-trending folds. No such arcuate features are apparent to the east and west of the shocked rocks, but instead, large north-northeast-south-southwest-trending faults are present. Many faults are marked by resistant sandstone sliding along lubricating 


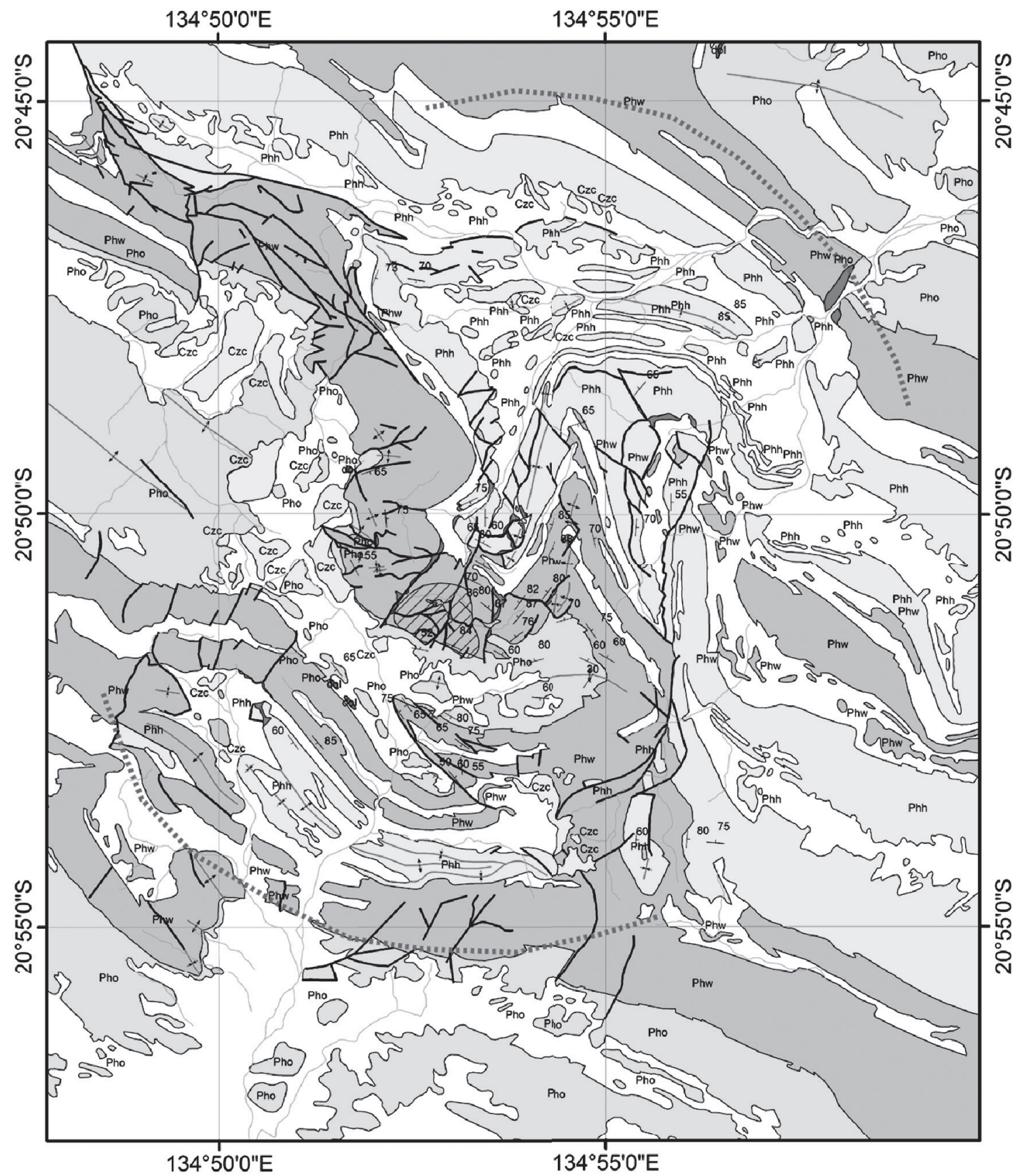

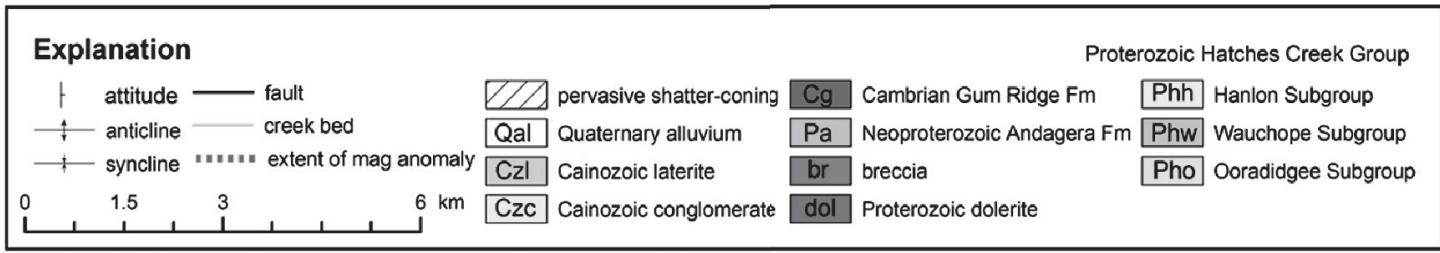

Figure 2 Geological map of the Amelia Creek impact structure. Extent of impact-related deformation is determined from arcuate features in ASTER, aeromagnetic, and X-SAR images (Figures 4, 5). Modified from Stewart et al. (1986b).

shale, siltstone, or volcanic rocks. Authigenic breccia is developed along fault zones, but no melt breccias or allogenic breccias were discovered despite a considerable search, implying at least a moderate level of erosion.

\section{GEOPHYSICS AND REMOTE SENSING}

The Amelia Creek structure has been examined using aeromagnetic, Advanced Spaceborne Thermal Emission and Reflection radiometer (ASTER), and X-band Syn- 


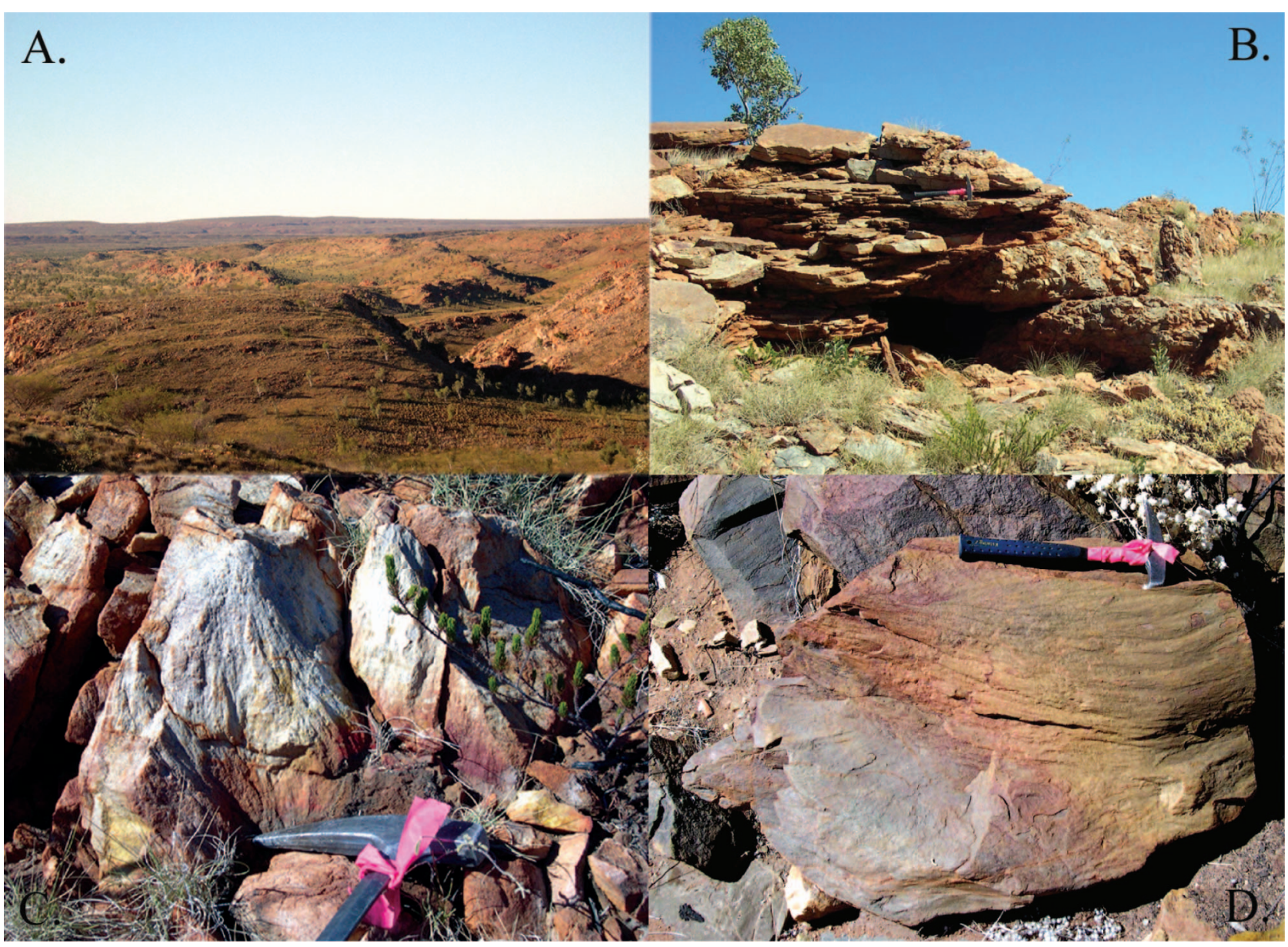

Figure 3 (a) Central syncline viewed from a sandstone ridge to the southwest (photograph shot at $20^{\circ} 50.7^{\prime} \mathrm{S}, 134^{\circ} 53.0^{\prime} \mathrm{E}$ ) near the northern margin of the area of pervasively shatter-coned rocks. (b) Stratified, post-impact, subhorizontal terrace deposits of the Neoproterozoic Andagera Formation located in the valley cutting the shatter-coned strata (20 $\left.51.0^{\prime} \mathrm{S}, 1^{134^{\circ}} 52.8^{\prime} \mathrm{E}\right)$. (c) Shatter cones in the Unimbra Sandstone with apices pointing nearly upward ( $\left.20^{\circ} 51.1^{\prime} \mathrm{S}, 134^{\circ} 53.0^{\prime} \mathrm{E}\right)$. (d) Giant shatter cone in felsic volcanics in the Yeeradji Sandstone of the Wauchope Subgroup (20 $\left.50.9^{\prime} \mathrm{S}, 134^{\circ} 52.9^{\prime} \mathrm{E}\right)$.

thetic Aperture Radar (X-SAR) images. These images confirm that the shocked rocks are centred on a wider area of deformation delimited to the north-northeast and south-southwest by arcuate features that interrupt regional trends at about a $20 \mathrm{~km}$ diameter, and by northnortheast-south-southwest-trending faults on the east and west sides at about a $12 \mathrm{~km}$ diameter. ASTER images clearly show the trends of folds and faults affecting the strata at the Amelia Creek structure (Figure 4).

Impacts can create magnetic anomalies by altering target rock magnetic properties or by creating circular structural patterns (Grieve \& Pilkington 1996). Highresolution digital aeromagnetic data for the Bonney Well 1:250000 map sheet area were released by the Northern Territory Geological Survey in 2001. The surveys were flown at $400 \mathrm{~m}$ line spacing along $90^{\circ}$ true constant latitudes, and the altitude specification was $60 \mathrm{~m}$ continuous ground clearance. Aeromagnetic images were processed at Geoscience Australia in Canberra using ER Mapper ${ }^{\mathbb{R}}$. As there are large regional gradients associated with the Precambrian folding, regional magnetic variations were removed by constraining the pixel threshold to the range of values in the central region of the structure. Thus the magnetic image is a relative measure and several areas outside of the central region are saturated (Figure 5a). The aeromagnetic signature of the Amelia Creek structure is dominated by the effects of recessive magnetic igneous rocks, and is thus essentially a negative image of the ASTER and X-SAR images, which highlight the non-magnetic sandstone ridges. Multiple arcuate features are apparent both to the north and south of the central shocked rocks, while the truncated linear forms occur to the east and west.

Radar images can be complementary to, or in some cases superior to, corresponding optical images for evaluating the size and structure of impact features (McHone et al. 2002). The X-SAR image (Figure 5b) was taken as part of the Space Radar Laboratory (SRL) experiment in 1994 with vertically polarised X-band $(\lambda=3 \mathrm{~cm})$. Images can be found at: < http:// www.op.dlr.de/ne-hf/SRL.html $>$. X-SAR images also show the trend of the deformed sandstone beds. Radar backscatter is sensitive to many parameters including vegetation, sub-metre-scale roughness, and the presence of boulders (McHone et al. 2002). In the image, blocky sandstone ridges are extremely reflective and light 


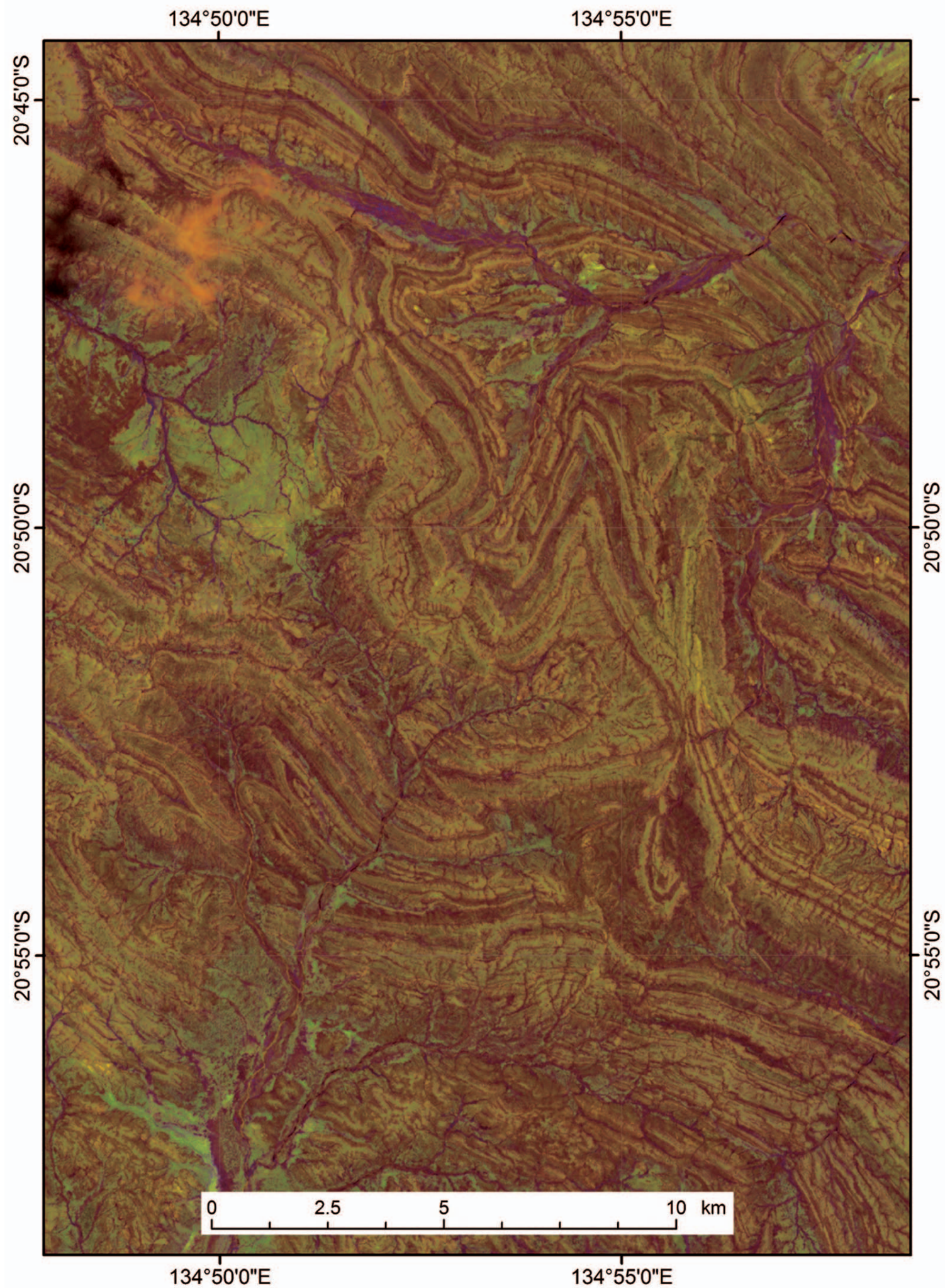

Figure 4 Advanced Spaceborne Thermal Emission and Reflection radiation (ASTER) image. Colours are not true, but instead represent specific bandwidths. The lighter rocks are largely sandstone ridges and superficial cover, and darker areas are recessive volcanics and younger sediments.

coloured, as are the boulder strewn creek beds, whereas the weathered volcanic rocks and plains that are relatively smooth appear dark.
These geophysical and remotely sensed images coupled with the geological map (Figure 2) delineate arcuate forms at a $\sim 20 \mathrm{~km}$ diameter north and south of 
Figure 5 (a) Residual aeromagnetic image of the Amelia Creek impact structure. (b) Xband Synthetic Aperture Radar (X-SAR) image of the Amelia Creek impact structure.
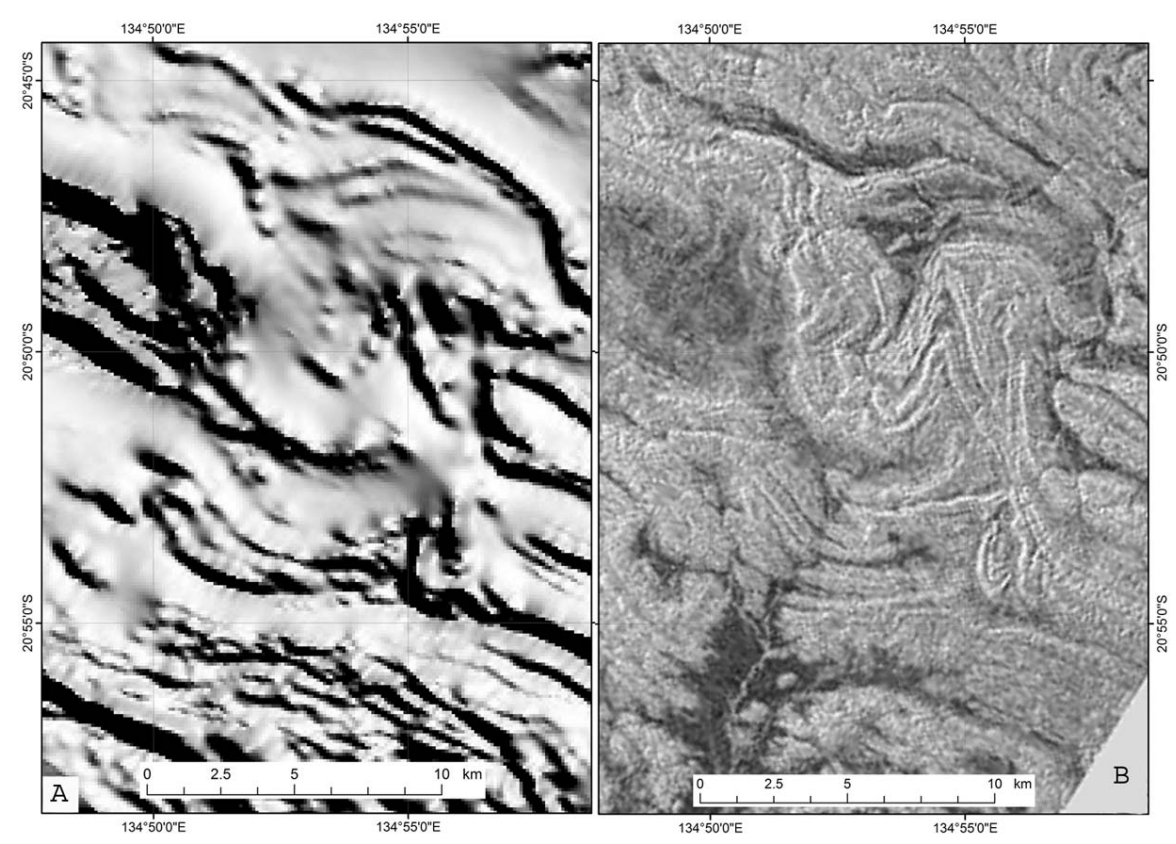

the central, shatter-coned region that appear independent of the regional tectonism and perhaps reflect the outer limit of impact-generated deformation.

\section{SHOCK-METAMORPHIC FEATURES}

\section{Shatter cones}

Shatter cones at Amelia Creek are ubiquitous in beds of the Unimbra Sandstone on the southern toe of the central syncline, and are typically oriented with the apex pointing upwards and at high angles to the bedding (Figure 3c, d). The surface distribution of shatter cones covers about $6 \mathrm{~km}^{2}$ in plan view (Figure 2). Within this zone, shatter coning is pervasive, and after Gosses Bluff (Milton et al. 1996), Amelia Creek is the most prolific shatter-cone locality in Australia. Shatter cones are also present in felsic volcanics in the Wauchope Subgroup, and form single cones nearly a metre in length (Figure $3 b)$. In the Yeeradgi Sandstone, shatter-cleavage overprints highly foliated rocks, indicating that the impact occurred after regional deformation. Although the striations of some shatter cones are curved (Figure $3 \mathrm{~b}$ ), this cannot be used as evidence for post-impact deformation as curvature in striations has been reported at other sites as a primary feature of shock metamorphism (Milton et al. 1996). Away from the toe of the central syncline, around the limbs of the fold, a similar stratigraphic sequence is present but shatter cones are rare or absent. An attempt was made to measure orientations of shatter-cone vertices as described by Milton et al. (1996). However, nearly all of the shatter cones are pointing within $\sim 15^{\circ}$ of vertical. As $15^{\circ}$ is also the approximate error in the measurements, the orientations failed to yield any distinguishing information. Nonetheless, when beds are rotated back to horizontal, the shatter cones are pointing southward at $\sim 5-10^{\circ}$ inclination.

\section{Shocked mineral grains}

Shocked quartz displays two distinct types of planar microstructures, planar fractures (PFs) and planar deformation features (PDFs). PFs are essentially cleavage in a quartz grain, forming sharp, parallel sets of straight fractures with more than $15 \mu \mathrm{m}$ spacing, whereas PDFs are planar, optical discontinuities of amorphous quartz, which form sets with $2-10 \mu \mathrm{m}$ spacing (Haines \& Rawlings 2002). The specific orientations of PDFs relative to the crystallographic axes of quartz grains can be used as a shock barometer (French 1998).

Thin-sections of shatter cones in the Unimbra Sandstone display planar microstructures in quartz grains (Figure 6), which appear to be cleavage and not true PDFs. Although cleavage in quartz grains has been observed frequently in association with PDFs (Kieffer 1971; Haines \& Rawlings 2002), it is thought to form at lower shock pressures ( $<7$ GPa: Stöffer \& Langenhorst 1994). The rarity or complete absence of cleavage in quartz grains in non-impact settings suggests that PFs can be used tentatively as an indicator of shock metamorphism (French et al. 2004), particularly where there exists other evidence of impact. The presence of PFs without obvious PDFs in shatter-coned rocks is not inconsistent, as shatter cones are thought to begin to form between 2 and $7 \mathrm{GPa}$, whereas PDFs form at shock pressures > $10 \mathrm{GPa}$ (French 1998). The apparent lack of PDFs may be due to a deep level of erosion, although PDFs have been difficult to locate at many impact structures developed in sedimentary targets, such as Upheaval Dome (Kriens et al. 1999), Glikson (Macdonald et al. 2005) and Rock Elm (French et al. 2004), and this may also reflect interstitial shock partitioning (Grieve et al. 1996). One common type of planar microstructure in quartz grains at Amelia Creek appears as incipient features stemming at an angle from planar fractures (Figure 6). We believe these 'feather features' are shock 


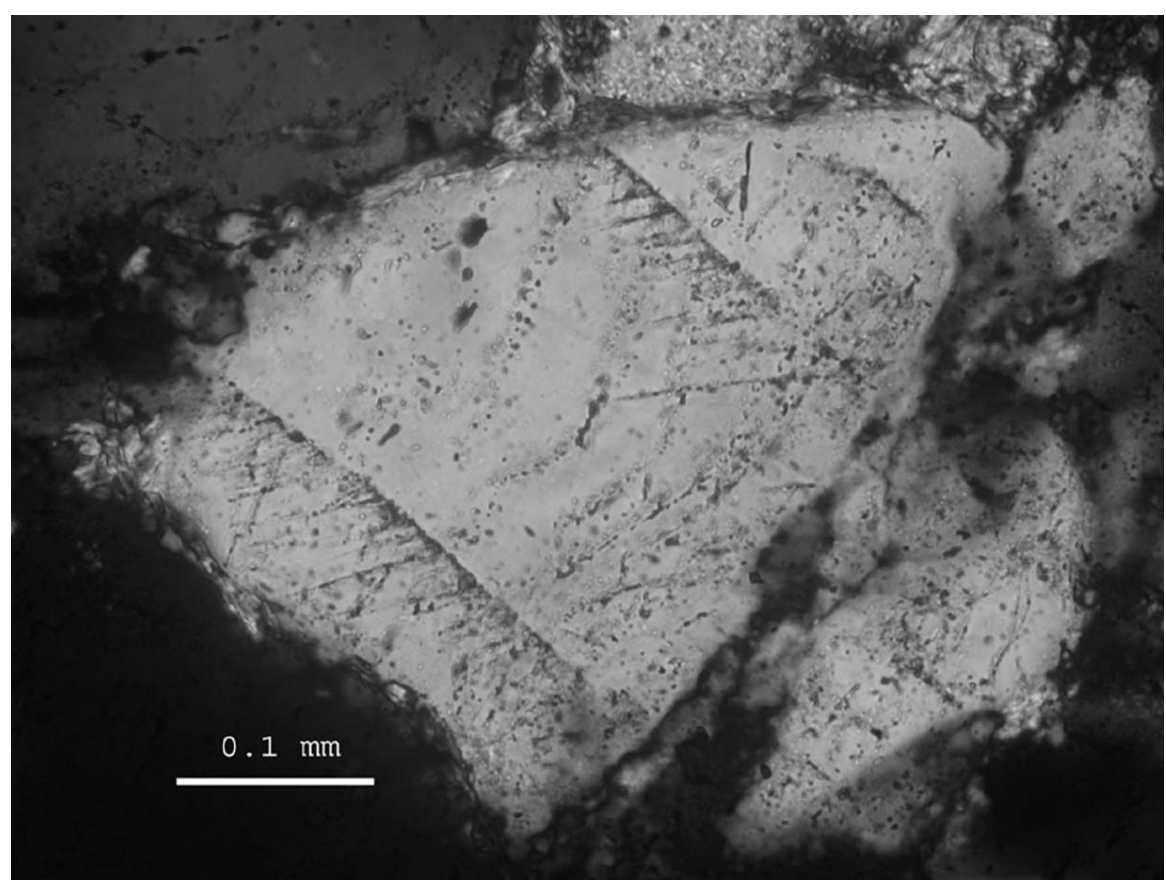

Figure 6 Photomicrograph with crossed-polars of 'feather features' in a quartz grain from the Unimbra Sandstone.

damage that formed as a precursor to PDFs; similar damage in quartz grains has been seen at other probable impact structures (French et al. 2004; Macdonald et al. 2005).

\section{DISCUSSION}

The impact event at Amelia Creek occurred before deposition in the Late Neoproterozoic, as sedimentary rocks of this age filling palaeovalleys cut into the shocked central region of the structure have not been deformed by impact (Figure $3 \mathrm{~b}$ ). However, it is unclear when in the Proterozoic the impact occurred and how the structure developed its aberrant form. The presence of a large, complex impact structure is suggested by the large area of pervasively shatter-coned rocks (3 x $2 \mathrm{~km}$ in plan view); however, no circular form, as characteristic of both complex impact structures with a central uplift and simple bowl shaped craters, is apparent. Below we discuss four alternative scenarios in an attempt to explain the peculiar geometry of the Amelia Creek impact structure.

(1) The impact occurred before or during the regional folding episodes and has thus been modified by postimpact tectonics. As shatter cones in folded sandstones point almost uniformly upwards at acute angles to bedding planes and overprint foliation, the impact clearly occurred after the formation of the broad northwest-trending anticline (ca $1700 \mathrm{Ma}$ ). Restoring this fold rotates the apical orientations of shatter cones to the south, inclined $\sim 5-10^{\circ}$ from the horizontal. Moreover, if the anticline formed after the impact we would expect shortening of the structure perpendicular to the fold axis. That is, an impact structure folded into an anticline would have older rocks in its core, whereas the shatter-coned syncline at Amelia Creek structure has younger rocks in its core.
Could the impact have occurred between the two folding events? In this scenario, formation of the central syncline after impact could explain the apparent lack of a central uplift. However, both sets of folds (northwest- and north-northeast-trending) formed under greenschist-facies metamorphic conditions, and so an impact between the two folding events would have hit the ground some $8-10 \mathrm{~km}$ above the present ground surface. But, the abundant and extensive shatter cones show that the present ground level is quite close-no more than $2 \mathrm{~km}$ depth-to the original impact point.

(2) The impact is deeply eroded and situated in complex terrain that obscures structural form characteristic of impact structures. If we assume instead that the impact occurred after all of the Palaeoproterozoic folding, and that the impact formed a standard complex impact structure with a circular outline and central uplift, then the structure must have been eroded to a level below the structural uplift. For a $20 \mathrm{~km}$ impact structure, this would be over $2 \mathrm{~km}$ of erosion (Grieve \& Pilkington 1996). Although this amount of erosion since the Proterozoic is certainly not impossible, the large area of pervasively shatter-coned strata and the arcuate forms to the north and south of the shocked rocks preclude deep erosion below the structural form. Alternatively, the bolide happened to impact directly on the toe of the central syncline and formed prolific shatter cones without imparting any appreciable structural uplift or circular form.

(3) The structure was formed in an extremely oblique impact. Several large, elongated terrestrial geological features lacking central uplifts have been sited as possible relics of extremely oblique impacts. For example, the Flaxman and Crawford structures in South Australia are trough-like, elliptical areas of deformation that harbour quartz grains with possible shock-induced planar microstructures (Haines et al. 
1999; Haines 2000); however, these sites have not been studied in detail, the structural forms are not understood, and an impact origin has not been confirmed. Shoemaker and Shoemaker (1996) also concluded that the asymmetries of the $\sim 13 \times 11 \mathrm{~km}$ Spider structure in the Kimberley region of Western Australia resulted from an extremely oblique impact. After reconnaissance, recognising the structural similarities between Spider and Amelia Creek, Macdonald and Mitchell (2003) followed the Shoemakers' lead and suggested that the asymmetries and the central syncline at Amelia Creek were the product of an oblique impact. If the bolide impacted at the geometrical centre between the arcuate forms in the geophysical images, that is, within the central syncline, then the position of the shocked rocks on the south-southwest side of the structure (thus, downrange) is consistent with an extremely oblique impact from the north-northeast (Dahl \& Schultz 2001), as is the lack of a central uplift, the faulting pattern to the east and west of the shocked rocks, and the somewhat symmetric arcuate pattern at $\sim 20 \mathrm{~km}$ diameter to the north and south of the central syncline (Gault \& Wedekind 1978; Schultz \& Anderson 1996). However, in such a geologically complex terrain it is difficult to differentiate these features from the regional tectonism, particularly as the central syncline appears to be one of four north-northeast-trending folds in the area, and the north-northeast-south-southwest faulting could also be related to transpression against the Taragan Block.

(4) The asymmetries in the target rock caused the central uplift to collapse into a syncline during the crater modification stage. Abels (2001) has argued that the unidirected thrust sheets at the Spider structure were controlled by pre-existing topography. The position of Spider on the axis of a syncline is analogous to Amelia Creek and suggests that the impact may have been centred along a steep-sided valley, which Abels (2001) argued could lead to asymmetric slumping. However, at Spider, an anomalously small ( $\sim 0.5 \mathrm{~km}$-wide) central uplift is developed at the head of the syncline (Shoemaker \& Shoemaker 1996), whereas Amelia Creek shows no signs of a central rebound. Like Amelia Creek, Spider is located in a fold belt and the asymmetries are roughly perpendicular to the trend of the fold axes and average regional strike. Perhaps this is a coincidence, or perhaps the asymmetries at both of these structures are a product of the pre-impact structure and topography of the target, and their central uplifts collapsed during the crater-modification stage. At Amelia Creek, asymmetrical deformation may have been facilitated by extreme strength differences between layers of subvertical, resistant, sandstone ridges and recessive volcanic rocks. A central uplift developed in upturned materials with very different strengths may be unstable and could collapse towards the weaker material during the crater-modification stage. However, once again, this model has difficulties explaining the position of the shocked rocks at the toe of the central syncline. In particular, if the impact somehow formed the north-northeast-trending syncline, is it merely a coincidence that there are three other northnortheast-trending folds in the region?

\section{CONCLUSIONS}

Amelia Creek is a unique terrestrial impact structure with well-developed shatter cones but no central structural uplift. Aeromagnetic, ASTER, and X-SAR images display arcuate features to the north and south of shocked rocks at $20 \mathrm{~km}$ diameter, yet it is unclear if this represents the original diameter of the structure. The obscure structural form can be reconciled if the impact occurred substantially later than the two Palaeoproterozoic folding events, possibly in the Neoproterozoic, after some $6-8 \mathrm{~km}$ of erosion had planed down the folded rocks to a level no more than about $2 \mathrm{~km}$ above their present level of exposure. The asymmetries at the Amelia Creek impact structure could be due to the preexisting structure of the target rock, and/or an oblique impact. Neoproterozoic palaeovalleys that cut the structure and are filled with unshocked Late Neoproterozoic and Middle Cambrian sediments, constrain the age of the impact to the Proterozoic.

\section{ACKNOWLEDGMENTS}

We are particularly thankful to Peter Schultz for his insights and support and Peter Haines for his thoughtful reviews. We would also like to thank Peter Milligan and Geoscience Australia for allowing us the use of aeromagnetic data and their image processing tools, the Thomas J. Watson Fellowship program and the Barringer Crater Company for providing support (to FAM), Winston Macdonald and John McHone for help in the field, and Joe Kirschvink and NASA's Astrobiology program for use of ASTER imagery.

\section{REFERENCES}

ABELS A. 2001. Integrated remote sensing of the Spider impact structure, Australia - Potential effects of the morphostructural setting on cratering. Proceedings Lunar and Planetary Science Conference XXXII, abstract 1408 .

Belton D. X., Brown R. W., Kohn B. P., Fink D. \& Farley K. A. 2004. Quantitative resolution of the debate over antiquity of the central Australian landscape: implications for the tectonic and geomorphic stability of cratonic interiors. Earth and Planetary Sciences Letters 219, 21-34.

Blake D. H., Stewart A. J., Sweet I. P. \& Hone I. G. 1987. Geology of the Proterozoic Davenport province, central Australia. Bureau of Mineral Resources Bulletin 216.

DAhl J. M. \& Schultz P. H. 2001. Measurement of stress wave asymmetries in hypervelocity projectile impact experiments. International Journal of Impact Engineering 26, 145-155.

DiETz R. S. 1959. Shatter cones in cryptoexplosion structures (meteoritic impact?). Journal of Geology 67, 496-505.

FRENCH B. M. 1998. Traces of catastrophe-a handbook of shockmetamorphic effects in terrestrial meteorite impact structures. Lunar and Planetary Science Institute, Houston, Contribution 954.

French B. M., Cordua W. S. \& Plescia J. B. 2004. The Rock Elm meteorite impact structure, Wisconsin: geology and shockmetamorphic effects in quartz. Geological Society of America Bulletin 116, 200-218.

Gault D. E. \& Wedekind J. A. 1978. Experimental studies of oblique impact. Proceedings Lunar \& Planetary Science Conference IX, $3843-3875$.

Grieve R. A. F., Langenhorst F. \& Stöffer D. 1996. Shock metamorphism of quartz in nature and experiment: II. Significance in geoscience. Meteoritics \& Planetary Science 31, 6-35. 
Grieve R. A. F. \& Pilkington M. 1996. The signature of terrestrial impacts. In: Glikson A. Y. ed. Australian Impact Structures, pp. 399-420. AGSO Journal of Australian Geology \& Geophysics 16

Haines P.W. 2000. Tsunami (?) deposit of terminal Eocene age, South Australia: the inferred effects of a low angle multiple impact event. Catastrophic Events and Mass Extinctions: Impacts and Beyond, Vienna, July 2000, abstract 3093.

Haines P. W., Bagas L., Wyche S., Simons B. \& Morris D. G. 1991. Barrow Creek SF53-6, 1:250000 Geological Map Series, Explanatory Notes. Northern Territory Geological Survey, Darwin.

Haines P. W. \& Rawlings D. J. 2002. The Foelsche structure, Northern Territory, Australia: an impact crater of probable Neoproterozoic age. Meteoritics \& Planetary Science 37, 269-280.

Haines P. W., Therriault A. M. \& Kelley S. P. 1999. Evidence for midCenozoic(?), low angle multiple impacts in South Australia. Meteoritics \& Planetary Science 34 (Suppl.), A49-A50.

Hargraves R. B., Cullicott C. E., Deffeyes K. S., Hougen S., Christiansen P. P. \& Fiske P. S. 1990. Shatter cones and shocked rocks in southwestern Montana: the Beaverhead impact structure. Geology 18, 832-834.

KIEFFER S. W. 1971. Shock metamorphism of the Coconino Sandstone at Meteor Crater, Arizona. Journal of Geophysical Research 76, $5449-5473$.

Kriens B. J., Shoemaker E. M. \& Herkenhoff K. E. 1999. Geology of the Upheaval Dome impact structure, southeast Utah. Journal of Geophysical Research 104, 18867-18887.

Macdonald F. A., Bunting J. A. \& Cina S. E. 2003. Yarrabubba-a deeply eroded major impact structure in the Yilgarn Craton, Western Australia. Earth and Planetary Science Letters 213, 235 247.

Macdonald F. A. \& Mitchell K. 2003. Amelia Creek, Northern Territory, Australia: a $20 \times 12 \mathrm{~km}$ oblique impact structure with no central uplift. Lunar and Planetary Science Institute, Houston, Contribution 1155, 47.

Macdonald F. A. \& Mitchell K. 2004. New possible, probable, and proven impact sites in Australia. Geological Society of Australia Abstracts 73, 407-420.

Macdonald F. A., Mitchell K. \& Wingate M. T. D. 2005. Geology and age of the Glikson impact structure. Australian Journal of Earth Sciences 52, 529-544.
McHone J. F., Greely R., Williams K. K., Blumberg D. G. \& Kuzmin R. O. 2002. Space shuttle observations of terrestrial impact structures using SIR-C and X-SAR radars. Meteoritics \& Planetary Science 37, 407-420.

Milton D. J., Glikson A. Y. \& Brett R. 1996. Gosses Bluff-a latest Jurassic impact structure, central Australia. Part 1: geological structure, stratigraphy, and origin. In: Glikson A. Y. ed. Australian Impact Structures, pp. 453-486. AGSO Journal of Australian Geology \& Geophysics 16.

RodDy D. J. \& Davis L. K. 1977. Shatter cones formed in large scale experimental explosion craters. In: Roddy D. J., Pepin R. O. \& Merrill R. B. eds. Impact and Explosion Cratering, pp. 715-750. Pergamon Press, New York.

Schultz P. H. \& ANDERson R. R. 1996. Asymmetry of the Manson impact structure: evidence for the impact angle and direction. In: Koeberl C. \& Anderson R. R. eds. The Manson Impact Structure, Iowa: Anatomy of an Impact Crater, pp. 397-417. Geological Society of America Special Paper 302.

Shoemaker E. M. \& Shoemaker C. S. 1996. The Proterozoic impact record of Australia. In: Glikson A. Y. ed. Australian Impact Structures, pp. 379-398. AGSO Journal of Australian Geology \& Geophysics 16.

SteWART A. J. 1987. Fault reactivation and superimposed folding in an Early Proterozoic sandstone-volcanic sequence, Davenport province, central Australia. Journal of Structural Geology 9 $441-456$.

Stewart A. J., Blake D. H. \& Ollier C. D. 1986a. Cambrian river terraces and ridgetops in central Australia: oldest persisting landforms? Science 233, 758-761.

Stewart A. J., Blake D. H. \& SweEt I. R. 1986b. Geology of the Kurundi Region, 1:100000 Geological Map. Bureau of Mineral Resources, Canberra.

StÖFFER D. \& LANGENHORST F. 1994. Shock metamorphism of quartz in nature and experiment: 1 . Basic observation and theory. Meteoritics \& Planetary Science 29, 155-181.

Received 29 May 2004; accepted 7 April 2005 